\title{
Study of Fish Diversity in Vaitarna River of Wada Taluka of Palghar District in Maharashtra, India
}

\author{
Snehal Subhash Donde ${ }^{1}$ and Akshay Laxman Patil ${ }^{2 *}$ \\ ${ }^{1}$ Shree Halari Visa Oswal College of Commerce, India \\ ${ }^{2}$ Environmental Study, Shree Halari Visa Oswal College of Commerce, India \\ *Corresponding author
}

\begin{tabular}{|l|}
\hline Ke y w o r d s \\
Wada Taluka, Fish \\
Diversity, \\
Actinopterygii, \\
Vaitarna River
\end{tabular}

\section{Introduction}

India has a rich biological background that show it is one of the nation with mega diversity of the world. There are 1000 of small and big rivers in India. Rivers are place of freshwater and are dynamic in environmental conditions. Rivers are areas of physical and biological transition between the lands. Importance of rivers is well understood in many parts of the world as breeding and
Study of biodiversity has become very essential for scientific data banking as unexpected abrupt climatic changes occurring regularly. This is mainly due to unchecked anthropogenic activities happening in the name of development. Riverine fishery is livelihood of many and also fish diversity of any region has great significance in environmental assessment of that region. The present research work was carried out to assess the fish diversity at Vaitarna River flowing in Wada Taluka region of Palghar district in Maharashtra. For the present study river water analysis of six villages and its fish diversity was accounted in context to the developments in the area such as industries, warehouses, etc. The finding of the study revealed that the quality of the river water is affected due to establishment of industries on the river bank and least attention of the authorities and non-adherence of the policies by the industries to compulsorily treat in in the fish market and among fishermen community revealed disappearance of many species and deteriorating quality of existing species. Only four species were identified and among this Actinopterygii was a major class of fish observed. Overall study revealed that Fish diversity along this region was less in comparison to previous years. Study of this nature is important for restoration of water bodies and revival of fish diversity and improving livelihood of poor fisherman community in the rural region. 
important groups of vertebrates influencing life in various ways. Fish plays an important role as it is not only useful for food but also be used in recreation and biological control. The Thane district (Now divided into two districts Thane and Palghar) alone shares about 23.6\% of the total fish landing from Maharashtra. Today rivers are heavily exploited and are among the most threatened ecosystems. Hence it is necessary to carefully asses the diversity status in these ecosystems. Present study deals mainly with diversity of fishes along Vaitarna River.

\section{Materials and Methods}

Vaitarna River was visited from $2^{\text {nd }}$ January 2018 to $16^{\text {th }}$ January 2018. The fishes were collected by local fishermen by using different type of nets $e . g$. Cast net, hand net, purse seine and gill nets.

Analysis of catch was done Analysis of catch was done. The fishes caught were examined for their colour or spots present on their body and recorded on the field. The species were ascertained on the basis of various morphometric characters with the help of Day (1888). This region has not assessed for any ecological study before. Hence, it is chosen to assess fish diversity.

\section{Results and Discussion}

The fish diversity at Vaitarna River from Wada was studied from $2^{\text {nd }}$ January 2018 to $16^{\text {th }}$ January 2018. The present study has revealed that there are about 4 fish species were observed during the span of two weeks of study. These 4 species were belonging to major class. Actinopterygii and only one species belong to Malacostraca. The quantity of fish has decreased compare to the previous year data with current year data due to the industrial setup and development at the bank of the river. This has led to the depletion of aquatic fauna and quality and quantity of the fish. The livelihood of fisherman is under threat in this area.

The water quality monitoring in this area is performed in order to determine the quality of water. Various parameters are analysed in the laboratory and 8 parameters are tested at field level. All these tasks recorded are utilized for preparing these report. This data is considered in order to specify the quality of water at each location. This also helps to determine the pollution level or concentration in each source of water at each station. The growing industries and release of effluents has led to contamination of water in this area which is analysed and noted below.

Study reveals that in recent period there is growing industrialization and other developments in Wada taluka of Palghar district in Maharashtra, India. Due to the development and several anthropogenic activities there is huge scarcity of water and available water is getting polluted, which is mainly due to failure of system with respect to water management and conservation initiatives. Vaitarana River which flow from Nashik district towards Palghar district in Maharashtra passes through Wada taluka. The banks of river and its tributaries in Wada region is getting polluted and almost dried in many areas. Water quality deterioration is evident from the physio-chemical analysis as shown in the findings of the water sample collected of the area (Fig. 1) water quality is deteriorating in this area. $\mathrm{pH}$ of the water is turning acidic. Hardness level of the water is also increased, as the physio-chemical parameter of water is affected. It has been reported by Chatterjee (2017) that the upper stretches of Vaitarna are clean but in lower stretches it's polluted due to untreated industrial and civic waste. All this have resulted in low fish production and fish catch in Wada Taluka. 
Previous status of fish in the river

\begin{tabular}{|c|c|c|c|c|c|}
\hline $\begin{array}{l}\text { Sr. } \\
\text { No }\end{array}$ & Class & Order & Family & $\begin{array}{c}\text { Genus and } \\
\text { species }\end{array}$ & $\begin{array}{c}\text { Local } \\
\text { Name }\end{array}$ \\
\hline 1 & Actinopterygii & Siluriformes & Clariidae & $\begin{array}{l}\text { C. } \\
\text { yariepinees }\end{array}$ & Mangur \\
\hline 2 & Actinopterygii & Perciformes & Percidae & $\begin{array}{l}\text { Percinae } \\
\text { perca }\end{array}$ & Rani \\
\hline 3 & Actinopterygii & Anguliformes & Congridae & $\begin{array}{c}\text { Congromura } \\
\text { naandgo }\end{array}$ & Vaam \\
\hline 4 & Malacostraca & Decapoda & Penaridae & $\begin{array}{l}\text { Fenneropen } \\
\text { arusindius }\end{array}$ & Kolambi \\
\hline 5 & Actinopterygii & Cypriniformes & Cyprinidae & Gibelion catla & a Catla \\
\hline 6 & Actinopterygii & Cypriniformes & Cyprinida & $\begin{array}{l}\text { Labeoninae } \\
\text { rohita }\end{array}$ & Rohu \\
\hline 7 & Actinopterygii & Peruformes & cinadae & $\begin{array}{l}\text { Tilapia } \\
\text { spramani }\end{array}$ & Tialapia \\
\hline
\end{tabular}

Current status of fish in the river

\begin{tabular}{|c|c|c|c|c|c|}
\hline $\begin{array}{l}\text { Sr. } \\
\text { No }\end{array}$ & Class & Order & Family & $\begin{array}{l}\text { Genus and } \\
\text { species }\end{array}$ & $\begin{array}{l}\text { Local } \\
\text { Name }\end{array}$ \\
\hline 1 & $\begin{array}{l}\text { Malaco } \\
\text { straca }\end{array}$ & Decapoda & Penaridae & Fenneropenarusindius & Kolambi \\
\hline 2 & $\begin{array}{l}\text { Actinop } \\
\text { terygii }\end{array}$ & Cypriniformes & Cyprinidae & Gibelion catla & Catla \\
\hline 3 & $\begin{array}{l}\text { Actinop } \\
\text { terygii }\end{array}$ & Peruformes & cinadae & Tilapia spramani & Tialapia \\
\hline 4 & $\begin{array}{l}\text { Actinop } \\
\text { terygii }\end{array}$ & Siluriformes & Clariidae & C. yariepinees & Mangur \\
\hline
\end{tabular}


Water analysis report

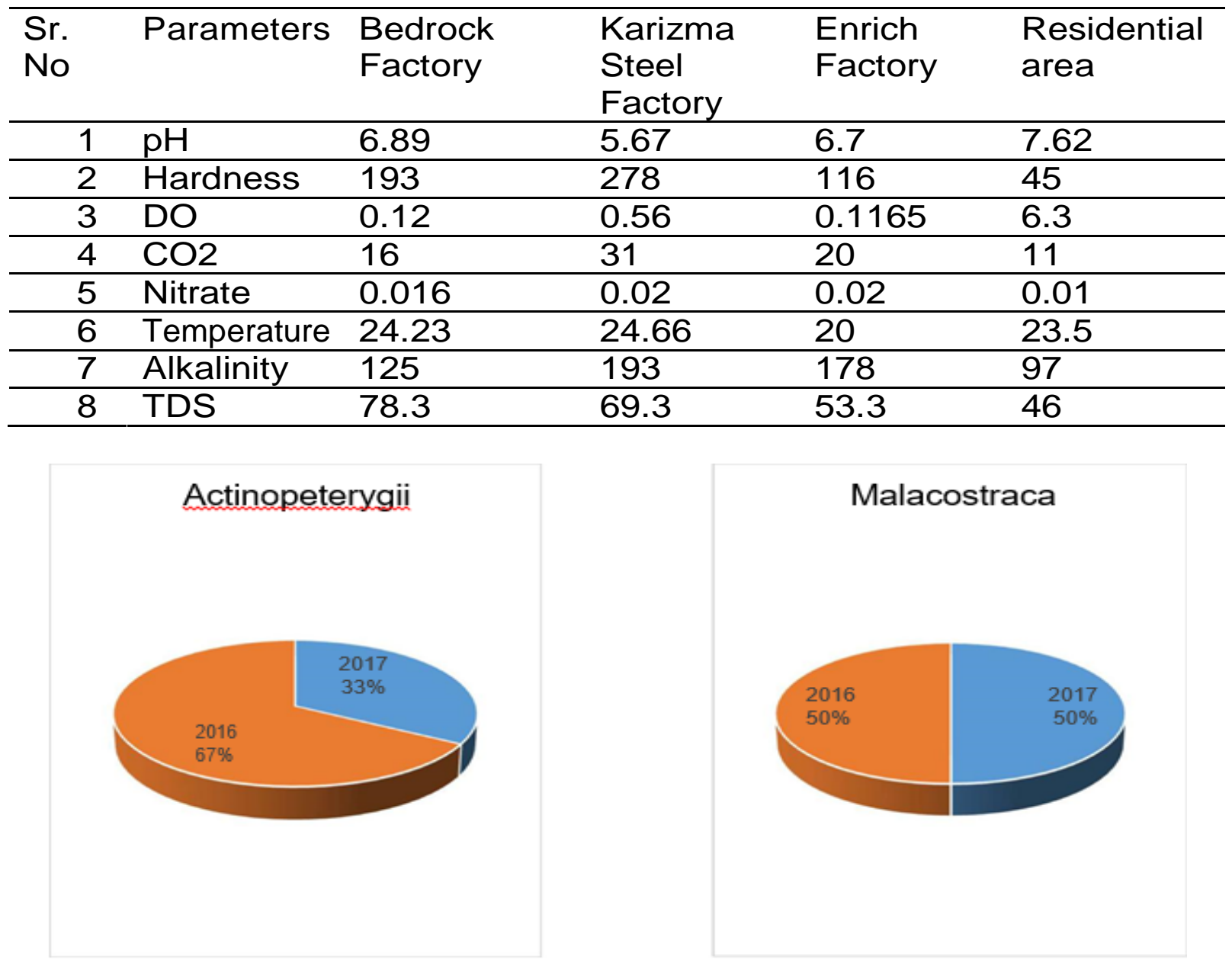

Status of fish in Vaitarna river

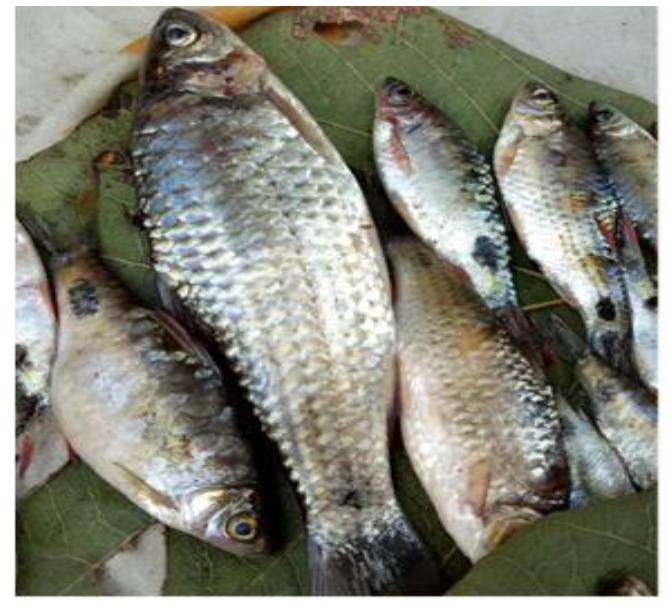

Gibelion Catla (Catla)

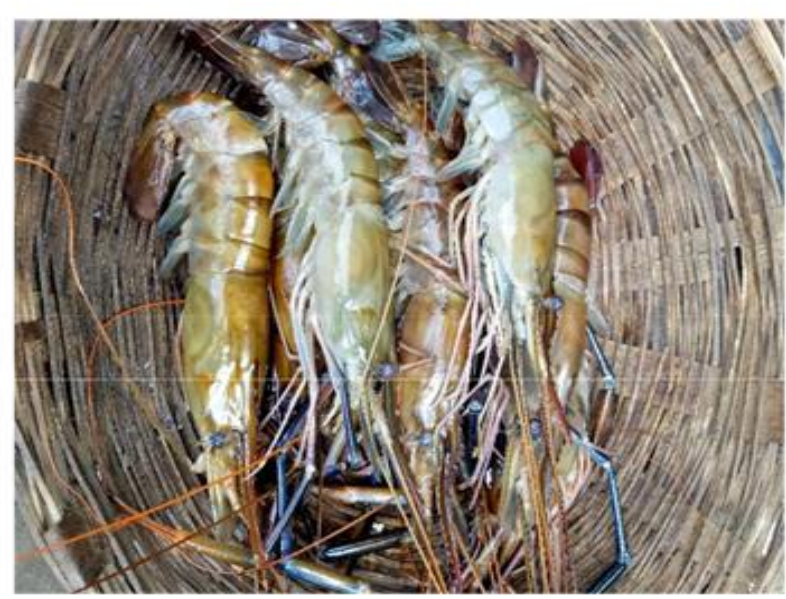

Fenneropenarusindius (Kolambi) 
Fig.1 Physio-chemical analysis of effluents from factories on river banks and water sample collected from catchment area

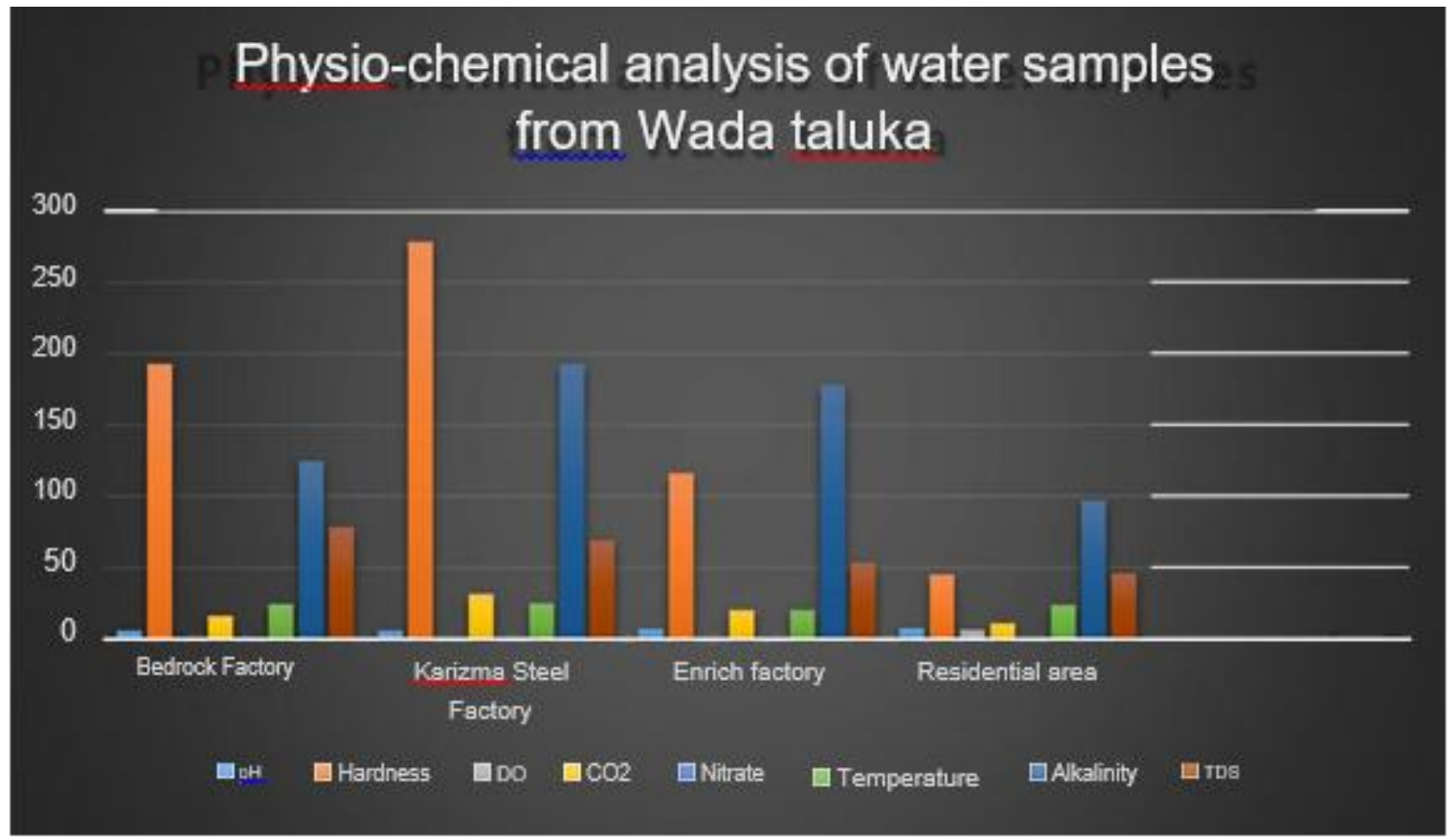

This led to the low income of the fisherman due to which they are involved in non-fishing activity. Thus to increase fish catch and fish production, for improving the livelihood of fisherman following recommendation are suggested:

Proper implementation of Government policy.

Introduction and training of new techniques in fishing should be provided to fisherman.

Industrial set up should be allowed with proper sewage treatment plant.

Continuous monitoring of Vaitarna River and its stream by NGO's, Government authorities with the help of students will help to create awareness in the community.

Such initiative will increase fish production in the Vaitarna River and its stream which will generate a good income to fishermen for upgrading their livelihood.

\section{References}

Badri Chaterjee (4 October 2017). "Maharashtra has the most polluted rivers in India: Report". Hindustan Times. Mumbai. Retrieved 18 October 2017.

Bal DV and Rao KV (1984). Marine Fisheries; Tata McGraw - Hill Publishing company Limited.

Balasubramanian T, Khan SA andRajendran N (2002). Estuaries of India: State of the Art Report. Environmental Information System Centre, Centre of Advanced Study in Marine Biology, Annamalai University, 1-2, 138-145.

Bharathirajan P, Muurugan S, Gopalkrishanan $A$ and Murugesan P (2015). Finfish diversity in Coleroon estuary, South east coast of India. Indian of GeoMarine Science, 44(1).

Breine J, Maes J, Ollevier F and Stevan M (2011). Fish assemblage across a salinity gradient in the Zeeschelde 
estuary (Belgium). Belgian Journal of Zoology, 141 21-44.

Chowdhury MSN, Hossain MS, Das NG and Barua P (2010). Environmental variables and fisheries diversity of the Naaf river estuary, Bangladesh. Journal of Coastal Conservation, 15(1) 163-180.

Dawson, London. Gadgil M (1996). Documenting diversity: An experiment. Current Science, 70: 36-44.

Day F (1888). The Fishes of India, being a Natural History of the Fishes known to inhabit the Seas and Freshwater of India, Burma and Ceylon, Supplement.

James NC, Cowley PD, Whitefield AK and Lamberth SJ (2007). Fish community in temporarily open and closed estuaries from the arm and cool temperate regions of South Africa - a review.

Jayaram KC (1981). Reviews in Fish biology and Fisheries, 17 565-580.

Jayaram KC (1981). The Freshwater Fishes of India, Pakistan, Bangladesh, Burma and Sri Lanka-A Hand Book, Director, Zoological Survey of India, Kolkata.
Joshi PS, Tantarpale VT and Kulkarni KM (2013). Fishing Methods Commonly Employed In Buldhana District and Neighborhood, Maharashtra State, India. Biosci. Disc., 4(1) 54-57.

Kumaran B, Naika S, Kambala R andNadarajan J (2012). Assessment of Ichthyo- faunal Diversity in Giriyampeta Estuary, Yanam (U.T. of Puducherry). Bulletin of Environment, Pharmacology and Life Sciences, 1(9) 17-25.

Lad D and Patil S (2013). Assessment of Fish Diversity in the estuarine area of Bhayander and Naigaon, Thane (M.S.) India. Science Research Reporter, 3(2) 229-232.

Nair V andJyothi A (1990). Fishery Potential of the Thana - Bassein Creek System. Journal of the Indian Fisheries Association, 20 7-10. Srivastava CBL (1999). A textbook of Fishery Science and Indian Fisheries. Kitab Mahal

\section{How to cite this article:}

Snehal Subhash Donde and Akshay Laxman Patil. 2018. Study of Fish Diversity in Vaitarna River of Wada Taluka of Palghar District in Maharashtra, India. Int.J.Curr.Microbiol.App.Sci. 7(05): 201-206. doi: https://doi.org/10.20546/ijcmas.2018.705.026 